
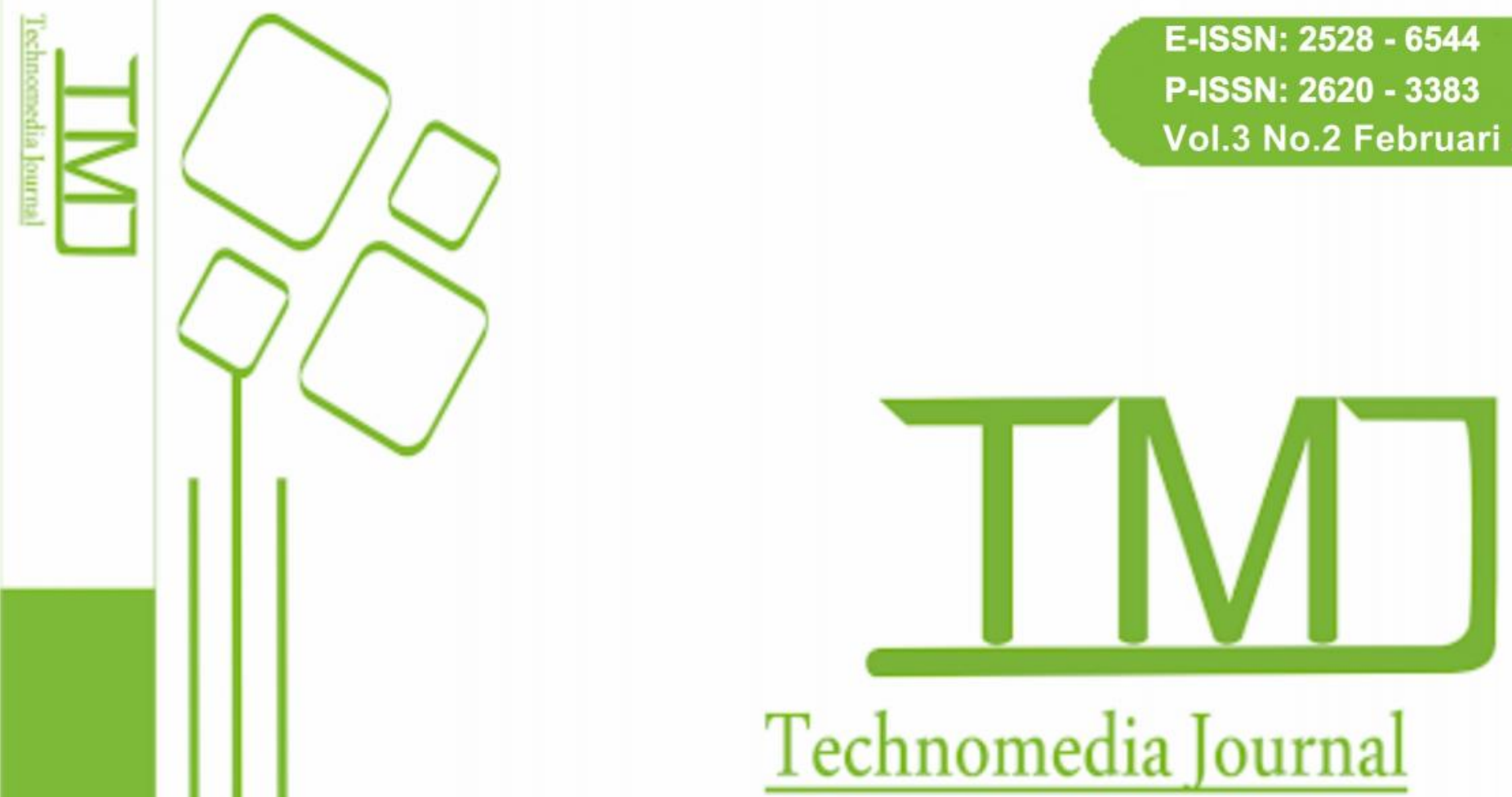

Technomedia Journal

iLearning Journal Center (iJC)

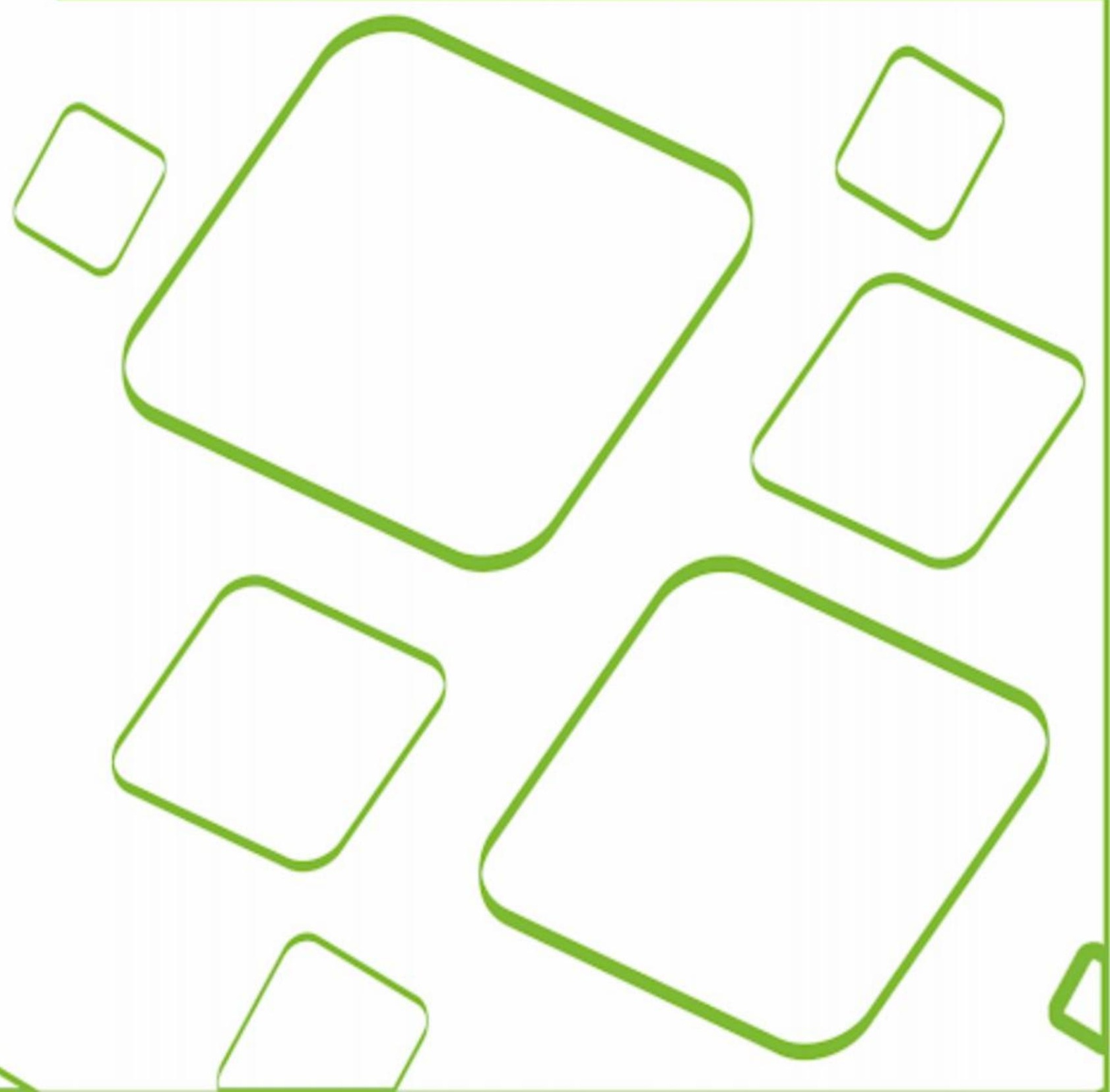




\title{
Penerapan Aplikasi Tawk To IduHelp! Sebagai Sarana Pelayanan Informasi di Perguruan Tinggi
}

\author{
Erick Febriyanto ${ }^{1}$ \\ Nurlaila Suci Rahayu Rais ${ }^{2}$ \\ Fikrah Syafa' $\mathrm{h}^{3}$ \\ Jurusan Sistem Informasi, STMIK Raharja, Tangerang \\ E-mail: erick@raharja.info ${ }^{1}$,nurlaila@raharja.info ${ }^{2}$, fikrah@raharja.info ${ }^{3}$
}

\begin{abstract}
ABSTRAK
Kemajuan teknologi saat ini berjalan dengan sangat cepat dan memberikan efek yang besar bagi kehidupan manusia, salah satunya dalam dunia pendidikan dan kegiatan. Pesatnya teknologi informasi ini, membuat instansi pendidikan juga menaikkan standar fasilitas sistem pelayanan informasi bagi Mahasiswa yang biasa disebut Tawk To. Tawk.to sendiri merupakan sebuah fitur chat online di iDuHelp! yang digunakan sebagai pelayanan informasi di Perguruan Tinggi Raharja yang diakses secara online dimana saja dengan menggunakan Rinfo dan sangat memudahkan mahasiswa jika ada kendala dalam perkuliahan.Pada sebelumnya pelayanan ini masih menggunakan metode chatting yang masih sederhana dan masih banyak kendala yang sulit diminimalisirkan namun dengannya adanya Tawk.to ini pelayanan informasi di Perguruan Tinggi Raharja menjadi sangat baik. Dalam sistem ini tidak hanya dapat melayani informasi seputar iLearning tapi layanan ini juga dapat membantu melayani kendala mengenai system Perguruan Tinggi yang dialami oleh Mahasiswa Perguruan Tinggi. Tulisan ini menyajikan perbandingan iDuHelp! dengan menggunakan Tawk.to dan dengan iDuHelp! dengan menggunakan chat sederhana. Dengan dibuatnya penelitian mengenai Tawk.to iDuHelp! ini diharapkan menjadi solusi untuk mahasiswa yang kesulitan dalam perkuliah dalam hal akdemik atau pun fasilitas lainnnya mengenai Perguruan Tinggi Raharja.
\end{abstract}

Kata Kunci : iDuHelp!, Pelayanan Informasi, Tawk.to

\section{ABSTRACT}

Technological advances are running very quickly and have a great effect on human life, one of them in the world of education and activities. The rapid information technology, making the educational institutions also raise the standard facilities of information service system for students who are usually called Tawk.to. Tawk.to itself is an online chat feature on iDuHelp! which serves as an information service at Higher Education Raharja which can be accessed online anywhere by using Rinfo and greatly facilitate students if there are obstacles in the 
lecture. In the previous service is still using the method of chatting is still simple and still many obstacles that are difficult diminimalisirkan but with it the Tawk To this information service in Higher Education Raharja be very good. In this information service system not only can serve information about ilearning but this service can also help to serve constraint about system of Higher Education experienced by University Students. This paper presents an iDuHelp comparison! by using Tawk To and with iDuHelp! using a simple chat. With the study of Tawk To iDuHelp! this is expected to be a solution for students who have difficulty in lecture in terms of akdemik or any other facilities about Raharja Higher Education.

Keywords: iDuHelp!, Information Services, Tawk To.

\section{PENDAHULUAN}

Pelayanan merupakan aktivitas yang dilakukan oleh perorangan atau kelompok melalui sistem tertentu untuk memenuhi kebutuhan dan memberikan kemudahan untuk mereka. hal ini menunjukan bahwa pelayanan merupakan sistem yang ditujukan untuk mereka yang membutuhkan suatu yang sesuai dengan dengan apa yang mereka harapkan.

Proses pelayanan dilakukan langsung dan rutin. Memberikan pelayanan terbaik merupakan upaya perusahaan untuk memberikan kepuasan bagi orang lain. Jika customer memberikan report pelayanan yang baik, berarti perusahaan sudah mampu memberikan pelayanan yang baik pula.

Perguruan Tinggi Raharja mempunyai sebuah sistem terbaru yang merupakan sebuah fasilitas pelayanan. Dimana pelayanan tersebut dipergunakan untuk seluruh Pribadi Raharja, dan pelayanan itu disebut iDuHelp! (iLearning Education Help) . Dengan adanya iDuHelp! Pribadi Raharja tidak akan kesulitan dalam mencari informasi yang bersangkutan dengan metode iLearning pada Perguruan Tinggi.

Dikutip dari jurnal Untung Rahardja, Fery sudarto dan Linda Octavia yang diterbitkan Perguruan Tinggi raharja, pada tahun 2013 yang berjudul Penerapan Campus Service Sistem iDuHelp! dalam Mendukung Kegiatan iLearning Education ( IDU ) Pada Perguruan Tinggi”, iDuHelp! yang merupakan sistem campus service system secara in site dan off site untuk mendukung semua kegiatan yang berhubungan dengan iLearning Education (iDu) pada Perguruan Tinggi yang nantinya Pribadi Raharja tidak mendapatkan kesulitan saat mencari informasi mengenai hal-hal yang bersangkutan dengan Kampus. 


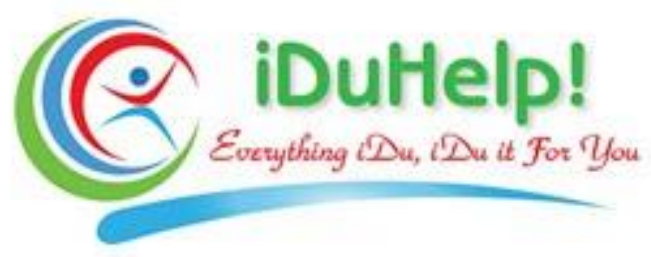

Gambar 1.1: Logo iDuHelp!

(Sumber: http://iduhelp.ilearning.me)

Dan diharapkan dengan adanya iDuHelp! ini Pribadi Raharja bisa mengetahui semua fasilitas dan berita dimiliki kampus tanpa harus mendatangi kampus. iDuHelp! juga salah satu bagian dari 10 Pillar IT iLearning ( TPi ), yang sangat membantu Pribadi Raharja dalam pembelajaran di iLearning. Apa itu iDuHelp!? iDuHelp sendiri dapat diartikan sebuah sistem campus service system dengan bentuk pelayanan secara in site dan off site untuk menunjang kegiatan iLearning Education (iDU).

Tawk To yang merupakan sebuah fitur chat online di iDuHelp! yang berguna untuk sebuah pelayanan informasi di Perguruan Tinggi Raharja. Fitur ini merupakan plug-in dari iDuHelp! yang bisa menghubungkan mahasiswa Raharja langsung kepada admin iDuHelp! yang akan melayani mahasiswa. Sebagai layanan online iDuHelp! Tawk to mempunyai jam operasi pada pukul 08:00 - 21:00.

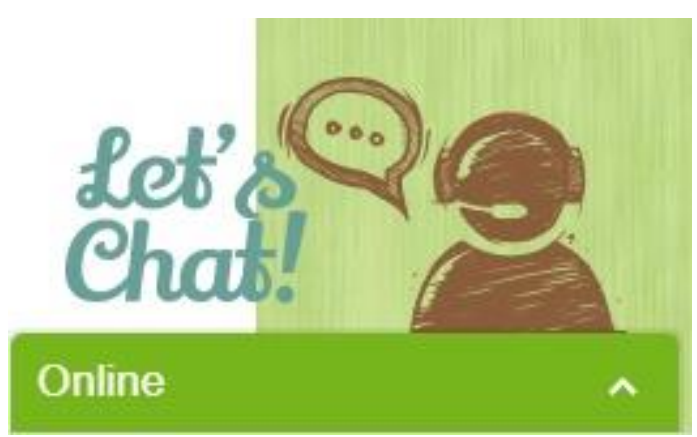

Gambar 1.2: Tampilan Tawk To. pada iDuHelp!

(Sumber : http://iduhelp.ilearning.me/ )

Sebelum menggunakan Tawk To, iDuHelp! Masih menggunakan sistem online yang berstandar magic.co dan masih sangat sederhana, dan saat ini iDuHelp! sudah menggunakan Tawk to sebagai sarana pelayanan informasi bagi mahasiswa Perguruan Tinggi Raharja, dimana semua mahasiswa raharja dapat mengaksesnya dimana saja dan kapan saja, sesuai jam opersi yang telah ditentukan.

\section{PERMASALAHAN}

Perguruan Tinggi Raharja adalah Perguruan Tinggi yang berbasis teknologi dan 248| Erick, Nurlaila, Fikrah - Penerapan Aplikasi Tawk To IduHelp! Sebagai Sarana ..... 
informasi. Perguruan Tinggi Raharja mempunyai beberapa sistem yang telah dikembangkan untuk bertujuan memudahkan Pribadi Raharja dalam mencari informasi secara efektif dan efisien. Salah satu sistem yang saat ini di kembangkan yaitu iDuhelp! yang khusus untuk fasilitas pelayanan informasi di Perguruan Tinggi Raharja, namun pemanfaatan sistem yang berjalan saat ini masih minim, yaitu hanya menggunakan chat sederhana.

Dengan menggunakn chat sederhana ini masih banyak permasalahan yang hadapi oleh iDuHelp! sebelum menggunakan Tawk.to adalah tidak mengetahuinya dari kualitas sebuah pelayanan pada iDuHelp! yang diberikan karena hanya dapat dirasakan oleh customer, sehingga operator iDuHelp! tidak dapat mengetahui suka tidak sukanya customer atas pelayanan yang diberikan oleh iDuHelp!. Sistem pelayanan iDuHelp! yang lalu masih jauh dari kata optimal dilihat dari tampilan dan kualitas pelayanannya. Perlu adanya perbaikan agar tampilan dan kualitas pelayanan mendapatkan respon yang sangat baik dari customer. Bukan hanya itu saja permasalahan yang ada di iDuHelp! sebelum menggunakan Tawk.to, dari segi interface kepada customer masih terlalu minim dan tidak menarik.

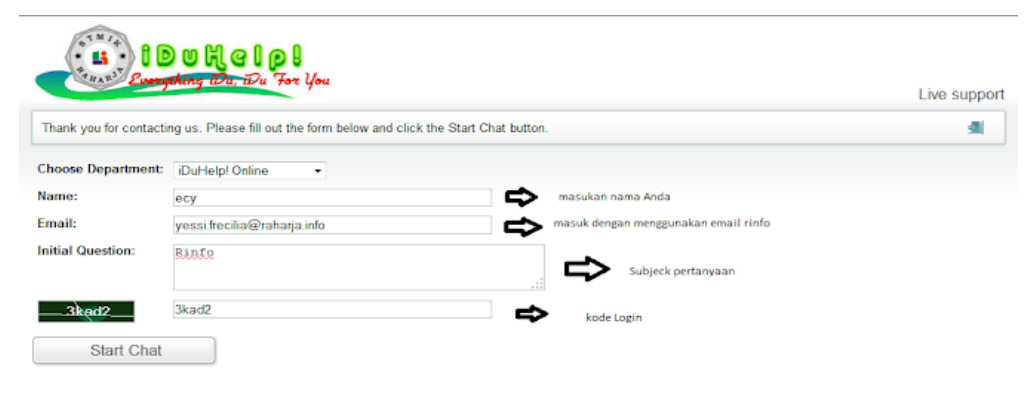

Gambar 3.1.1. Tampilan awal masuk iDuHelp! untuk customer sebelum menggunakan Tawk.to

(Sumber : http://iran.raharja.info)

Gambar diatas merupakan tampilan awal masuk iDuHelp! Untuk customer sebelum menggunakan Tawk.to. Dimana terlihat sangat tidak efektif karena harus mengisi departemen, nama, e-mail dan inti pertanyaan sebelum memulai untuk chat dengan petugas. Cara ini tidak efektif karena mamakan waktu. 


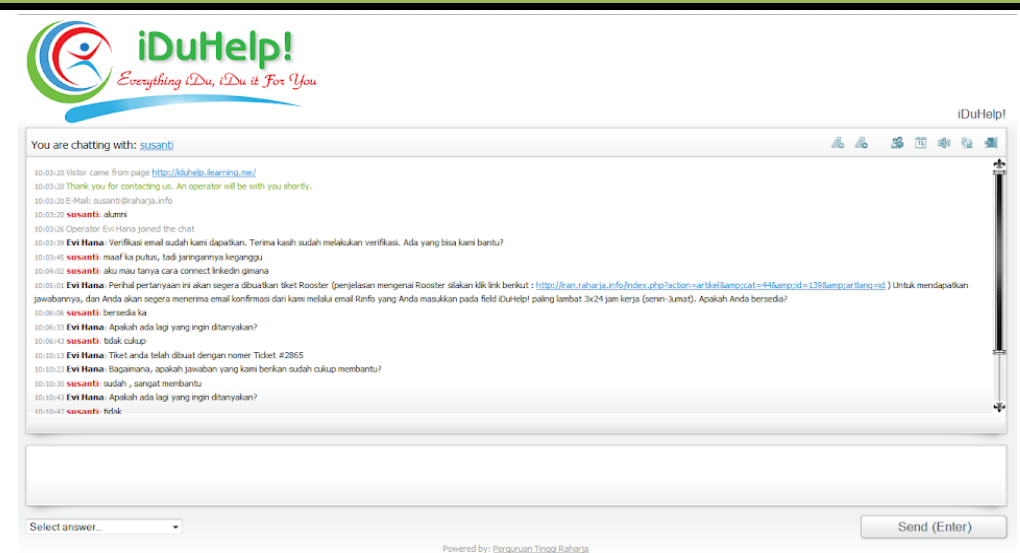

Gambar 3.1.2. Tampilan chat iDuHelp! untuk customer sebelum menggunakan Tawk.to (Sumber : http://evihanayanti.ilearning.me/2015/03/13/idu-help/)

Gambar diatas merupakan tampilan chat iDuHelp! untuk customer sebelum menggunakan Tawk.to. Dimana terlihat tampilan yang kurang seperti "chat" pada umumnya, sulit dibaca dan juga terlihat perbedaan chat dari customer dan petugas hanya dibedakan dari warna saja namun tidak dengan posisi chat, karena posisi chat pada umumnya yang menggunakan "bubble" chat dan posisi "bubble" chat pada customer berada disebalah kiri dan petugas sebelah kanan.

\section{METODOLOGI PENELITIAN}

Keterangan :

1. Metode Observasi dilakukan secara langsung di Perguruan Tinggi Raharja

2. Perbandingan antara metode iDuHelp! online menggunakan magic.co dengan metode iDuHelp! Online yang sekarang, yaitu Tawk To.

3. Penerapan Tawk To ke dalam iDuHelp!

Berikut ini adalah beberapa literatur perbandingan sistem yang digunakan dalam penelitian ini :

1. Penelitian yang dilakukan oleh Untung Rahardja, Fery Sudarto dan Linda Octavia dari Perguruan Tinggi raharja, pada tahun 2013 yang berjudul “ iDuHelp!" : "Penerapan Campus Service Sistem iDuHelp! Dalam Mendukung Kegiatan iLearning Education ( IDU ) Pada Perguruan Tinggi”. Penelitian ini menjelaskan tentang sebuah campus service berbasis Online dan Offline. Dengan penerapan iDuHelp! dimanfaatkan sebagai kegiatan iLearning Education pada Perguruan Tinggi Raharja.

2. Penelitian yang dilakukan oleh Eva Rosyifa dari Perguruan Tinggi Raharja, Indonesia, pada tahun 2012 yang berjudul "Penerapan Campus Service System_iDuHelp! dalam Mendukung Kegiatan iLearning Education (iDu) Pada Perguruan Tinggi Raharja”. 
Penelitian ini menerangkan tentang sebuah pelayanan chatting secara online dan offline Perguruan Tinggi Raharja, yang difasilitaskan untuk Pribadi Raharja yang mana ingin medapatkan informasi seputar akademik, dan diperuntukan calon mahasiswa yang ingin mengetahui informasi kampus.

3. Penelitian yang dilakukan oleh Hani Dewi Ariessanti, Erick Febriyanto, Nida Hanifah dengan judul yaitu "Pelayanan Sistem Iduhelp (iLearning Education Help) dengan menggunakan sistem iLearning Survey Pada Perguruan Tinggi" Penelitian ini menjelaskan tentang perkembangan dari teknologi dalam dunia informatika, maka dengan menggunakan iDuHelp!, mempermudah Pribadi Raharja untuk mendapatkan informasi yang bersangkutan dengan iLearning.

4. Penelitian yang dilakukan oleh Rismawati Kurniasari yang berjudul "Notulen Online Pada Perguruan Tinggi Raharja". Penelitian ini tentang pelayanan untuk memenuhi kebutuhan mahasiswa yang semakin bertambah dan belum terpenuhi. Sehingga pengolahan datanya dapat dilakukan secara terkomputerisasi dan maksimal.

5. Penelitian yang dilakukan oleh Indri Handayani, Herrafika Kusumahati, Alpiah Nurul Badriah dengan judul "Pemanfaatan Google Spreadsheet Sebagai Media Pembuatan Dashboard pada Official Site iFacility di Perguruan Tinggi”. Penelitian ini membahas pemanfaatan Dashboard iFacility yang bergunaka untuk memberikan sebuah informasi dan memudah mengetahui permasalahan yang sering terjadi, dapat memberikan data secara real time.

6. Penelitian yang dilakukan oleh Roni Setiawan dan Edhy Sutanta dengan judul "Membangun Aplikasi Chating berbasis Multiuser" yang menjelaskan tentang sebuah program aplikasi chatting yang dikembangkan menjadi sebuah alternatif solusi media komunikasi bagi para pengguna dalam jangkauan kecil.

Kemudian dari 6 literatur yang digunakan dapat disimpulkan bahwa Tawk.to merupakan sarana yang sangat tepat sebagai media informasi kampus yang menunjang untuk kemudahan mahasiswa untuk menanyakan kesulitan tentang berbagaimacam hal yang berkaitan dengan Kampus.

\section{HASIL DAN PEMBAHASAN}

\section{A. Pemecahan Masalah}

Untuk mengatasi beberapa masalah di atas, maka dibutuhkannya sebuah proses yang cepat dan tepat dalam mengakses seluruh informasi yang ada disebuah Perguruan Tinggi. Kecanggihan dari teknologi yang semakin canggihs dapat mempermudah menciptakan sebuah sistem dan pengambilan keputusan yang lebih efektif.

Dikutip dari website https://www.tawk.to/ "Tawk.to is a free messaging that lest you monitor and chat with visitor on your website, mobile app or from a free customizable page". Sebagai pemanfaatan dari kemajuan teknelogi penulis ingin menerapkan sistem Tawk.to pada 
iDuHelp! dimana Tawk.to merupakan suatu live chat app yang berfungsi untuk berbicara langsung oleh pengunjung dengan Operator.

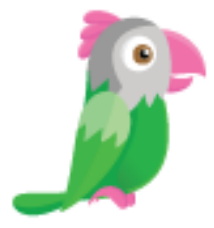

Gambar 3.2.1 Logo Tawk.to

(Sumber : https://www.tawk.to/)

Penulis akan menjabarkan pemecahan masalahnya dari mulai perbandingan sampai dengan penerapannya. Berikut penjabarannya :

1. Perbandingan antara iDuhelp! lama dengan iDuHelp! yang menggunakan Tawk.to

\section{a. Perbandingan log-in operator}

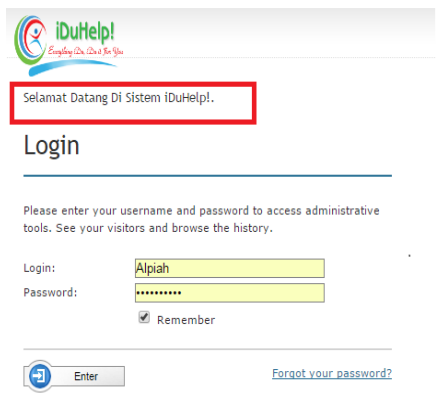

Gambar 3.2.1 Tampilan log-in iDuHelp! untuk operator sebelum menggunakan Tawk.to

(Sumber : http://timur.ilearning.me/2017/04/17/update-sistem-iduhelp/)

Gambar diatas merupakan tampilan login untuk operator iDuHelp! menggunakan magic.co. Di dalam iDuHelp! Yang menggunakan magic.co ini username dan password untuk operator ditentukan PIC (Person In Charge) iDuHelp! yang dikirimkan via e-mail. 


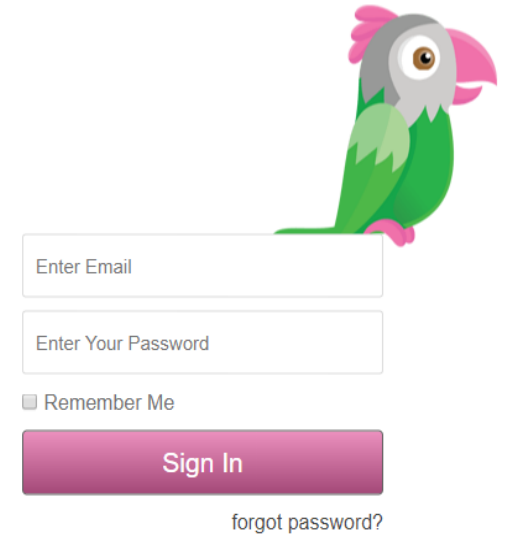

Gambar 3.2.2 Tampilan log-in iDuHelp! dengan menggunakan Tawk.to

(Sumber : https://dashboard.tawk.to/)

Gambar di atas merupakan log-in untuk operator pada iDuHelp! Yang sudah menggunakan Tawk.to. Pada iDuHelp! Yang sudah menggunakan Tawk.to ini operator dapat menentukan username dan password sendiri untuk Log-in Tawk.to

\section{b. Perbandingan tampilan record chat}

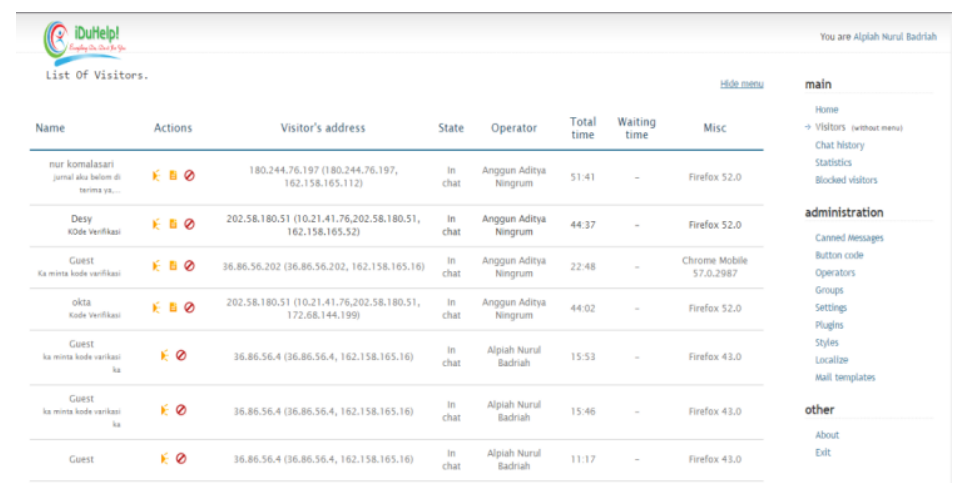

Gambar 3.2.3 Tampilan hasil record chat operator iDuHelp! menggunakan magic.co

(Sumber : http://timur.ilearning.me/2017/04/17/update-sistem-iduhelp/)

Gambar diatas merupakan tampilan dari record chat dari iDuHelp! Yang menggunakan magic.co. Terlihat dari segi tampilan record iDuHelp! masih kurang dan masih perlu perbaikan karena tampilannya tidak mudah dipahami.

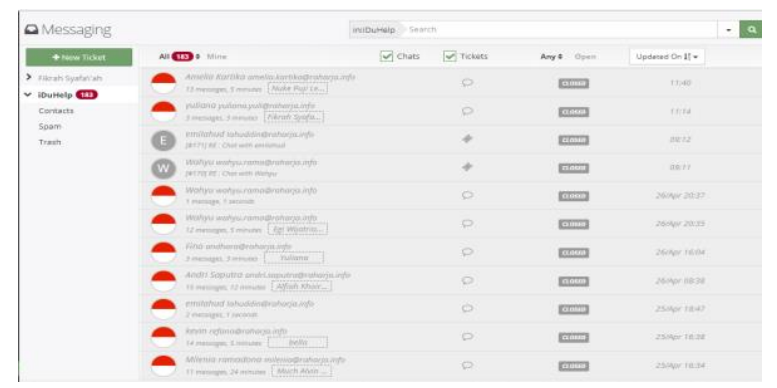


Gambar 3.2.4 Tampilan record chat operator iDuHelp! menggunakan Tawk.to

(Sumberb : https://dashboard.tawk.to/\#/messaging)

Gambar diatas merupakan tampilan dari record chat dari iDuHelp! Yang menggunakan Tawk.to terlihat dari segi tampilan record chat iDuHelp! lebih mudah dipahami dan lebih terperinci, sehingga PIC iDuHelp! Lebih mudah mengecek dan mengaudit operator jika melakukan kesalahan.

\section{c. Perbandingan tampilan chat Operator}

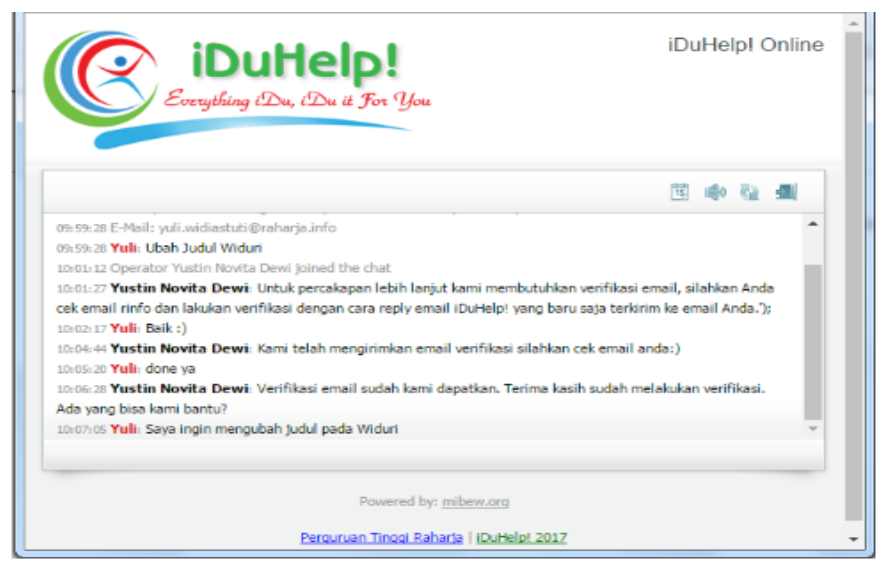

Gambar 3.2.5 Tampilan chat operator iDuHelp! menggunakan magic.co

(Sumber : http://timur.ilearning.me/2017/04/17/update-sistem-iduhelp/)

Dan dari segi tampilan pada chat masih sulit dipahami karena antara customer dan operator hanya dibedakan dengan warna pada namanya saja, jadi sulit membedakan antara customer dan operator.

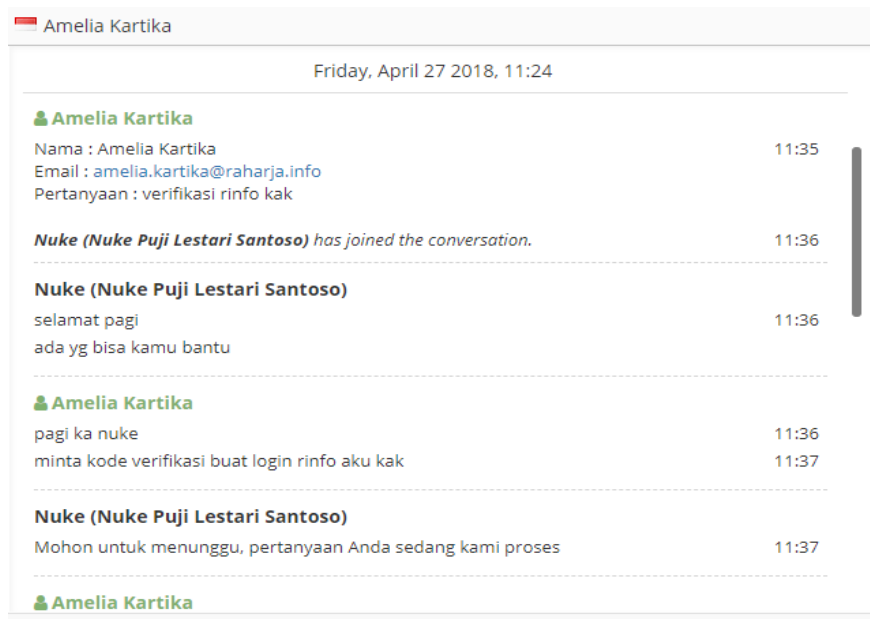

Gambar 3.2.6 Tampilan chat operator iDuHelp! menggunakan tawk.to (Sumber : https://dashboard.tawk.to/\#/messaging) 
Dan dari segi tampilan pada chat untuk operator juga lebih mudah dipahami karena ada perbedaan warna dan juga dibatasi oleh garis, dan juga lebih menarik. Dan operator juga lebih memudah memahami chat dari customer.

\section{d. Perbandingan tampilan chat customer}

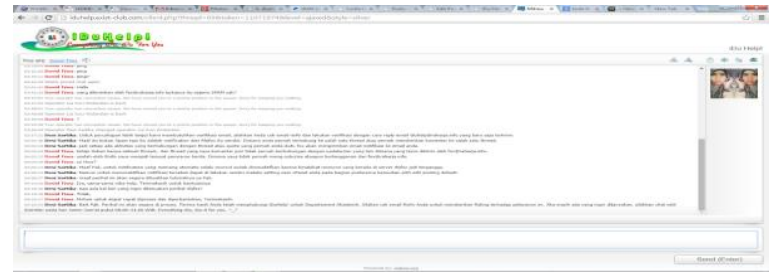

Gambar 3.2.7 Tampilan chat customer iDuHelp! menggunakan magic.co (Sumber : http://mit.ilearning.me/idu-help-everything-idu-idu-it-for-you/)

Dan dari segi tampilan pada chat masih sulit dipahami karena antara customer dan operator hanya dibedakan dengan warna pada namanya saja, jadi sulit membedakan antara customer dan operator. Hanya dibedakan dengan adanya foto dari operator yang sedang menangani.

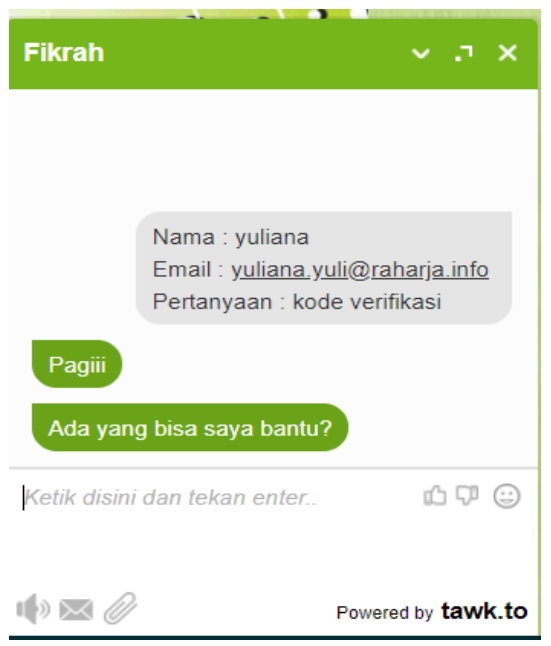

Gambar 3.2.7 Tampilan chat customer iDuHelp! Menggunakan tawk.to (Sumber : https://dashboard.tawk.to/)

Gambar diatas merupakan tampilan live chat dari Tawk.to, yang menggunakan bubble chat yang lebih mudah dibedakan antara chat dari customer dan chat dari operator. Dan tampilan live chat Tawk.to lebih terlihat modern karena disertakan dengan button like, unlike, dan emoticon.

Dari perbandingan antara iDuHelp! magic.co dengan iDuHelp! Tawk.to sangat lah terlihat perbandingannya, iDuHelp! Tawk.to jauh lebih modern dan jauh lebih nyaman dari 
segi tampilan hingga pengoperasiannya dibandingkan dengan magic.co. Untuk itu Perguruan tinggi Raharja memutuskan untuk mengganti iDuHelp! magic.co dengan iDuHelp! Tawk.to untuk mempermudah mahasiswa dalam mencari tahu informasi yang berkaitan dengan kampus dan ruang lingkupnya.

\subsection{Implementasi}

1. Pertama masuk ke dalam dashboard (viewboard).

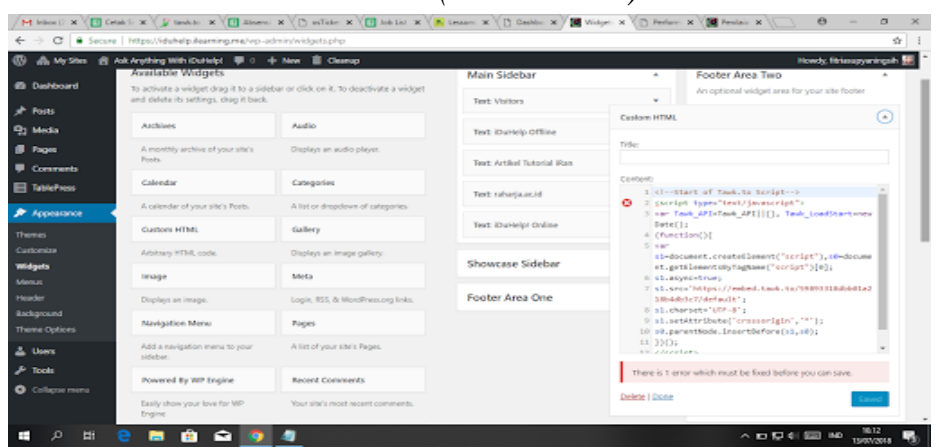

Gambar 3.3.1. Page iDuHelp!

Gambar diatas merupakan page yang ada di dalam official site iDuHelp! yaitu perihal page dashboard (viewboard) yang digunakan untuk mengedit bagian tampilan dashboard pada page tersebut.

2. Untuk selanjutnya yang dilakukan adalah embed codingan dari Tawk.to. Sebelum itu kita harus masuk ke dalam Tawk.to selaku admin dan copy codingan

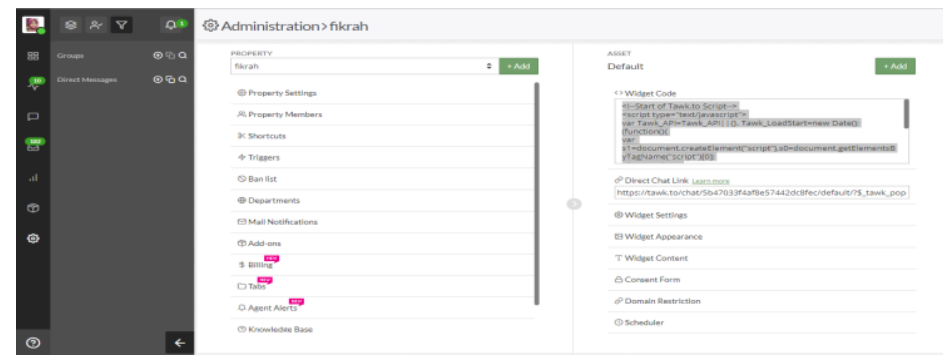

Gambar 3.3.2. Cara mengambil codingan embed tawk.to

Gambar di atas merupakan cara mengambil link pada dashboard yang datanya telah terangkum dan telah dibuat untuk di embed ke dalam Official site iDuHelp!.

3. Paste codingan yang sudah di copy tersebut ke dalam widget pada bagian footer are official site iDuHelp! Di bawah ini : 


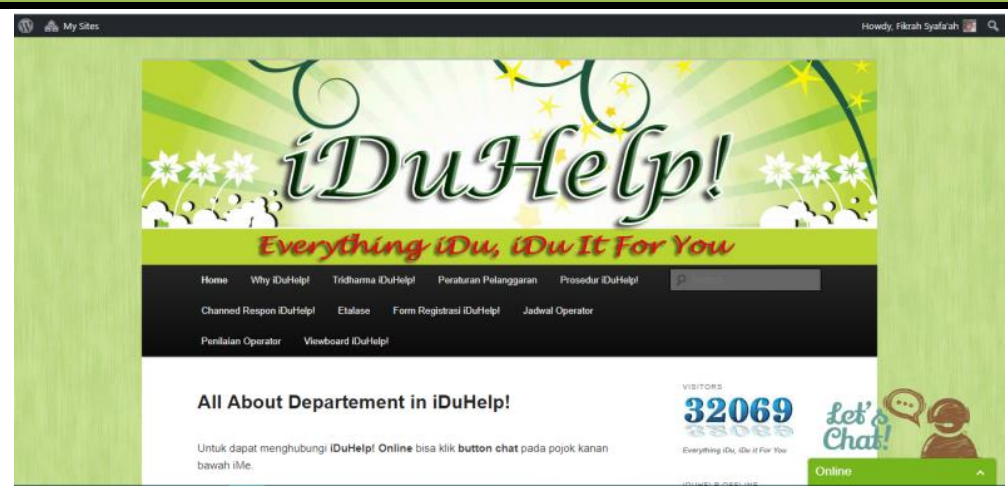

Gambar 3.3.4.. Hasil akhir tampilan tawk.to pada iDuHelp!

Gambar di atas merupakan hasil akhir tampilan Tawk.to yang telah di save di dalam official site iDuHelp!. Terdapat live chat yang berguna untuk mahasiswa yang ingin bertanya mengenai kampus, yang bisa diakses dalam official site iDuHelp!.

\section{KESIMPULAN}

Dapat disimpulkan bahwa pemanfaatan tawk.to pada iDuHelp! telah sesuai dengan kebutuhan - kebutuhan yang ingin ditampilkan. Maka dapat disimpulkan dengan adanya iDuHelp! Dengan Tawk.to ini dapat :

1. iDuHelp! Tawk.to dapat memberikan informasi dengan menggunakan live chat kepada mahasiswa.

2. iDuHelp! Tawk.to dapat memberikan informasi secara tepat dan akurat.

3. Dengan adanya iDuHelp! Tawk.to ini memudahkan mahasiswa untuk menanyakan hal yang berhubungan dengan kampus.

4. iDuHelp! Tawk.to ini dapat membuat nyaman mahasiswa dalam menanyakan informasi dari segi tampilan yang modern dan fasilitas yang diberikan.

\section{SARAN}

Berdasarkan keseluruhan yang telah penulis uraikan maka dengan ini penulis dapat menyimpulkan saran yaitu sebagai berikut ini :

1. Perlunya pengembangan tampilan supaya lebih menarik dan lebih baik.

2. iDuHelp! Tawk.to ini mempunyai auto chat untuk mempermudah ketika live chat berlangsung.

\section{DAFTAR PUSTAKA}

Ariessanti, H. D., Febriyanto, E., \& Hanifah, N. (2014). PELAYANAN SISTEM IDUHELP (ILEARNING EDUCATION HELP) DENGAN MENGGUNAKAN SISTEM ILEARNING SURVEY PADA PERGURUAN TINGGI. CCIT Journal, $8(1), 137-152$ 
Batinggi, A., \& Ahmad, B. (2014). Manajemen Pelayanan Umum..

Handayani, I., Aini, Q., \& Oktavyanti, Y. (2015). Penggunaan RinfoCal Sebagai Aplikasi Pengingat (Reminder) Kegiatan Akademik Pada Perguruan Tinggi. CCIT Journal, 9(1), 13-26.

Rahardja, U., Yusup, M., \& Astuti, E. (2014). Penerapan Sistem Integrated Raharja Multimedia E-Portfolio (IRME) Cv Online Pada Perguruan Tinggi Raharja. CCIT Journal, 7(2), 205-221.

Sunarya, A., Rahardja, U., \& Wanda, A. (2015). KEPUASAN PELANGGAN ROOSTER ATAS KINERJA PELAYANAN ROOSTER PADA PERGURUAN TINGGI RAHARJA. CCIT Journal, 9(1), 87-99.

Handayani, I., Kusumahati, H., \& Badriah, A. N. (2017). Pemanfaatan Google Spreadsheet Sebagai Media Pembuatan Dashboard pada Official Site iFacility di Perguruan Tinggi. Sisfotenika, 7(2), 177-186. 